
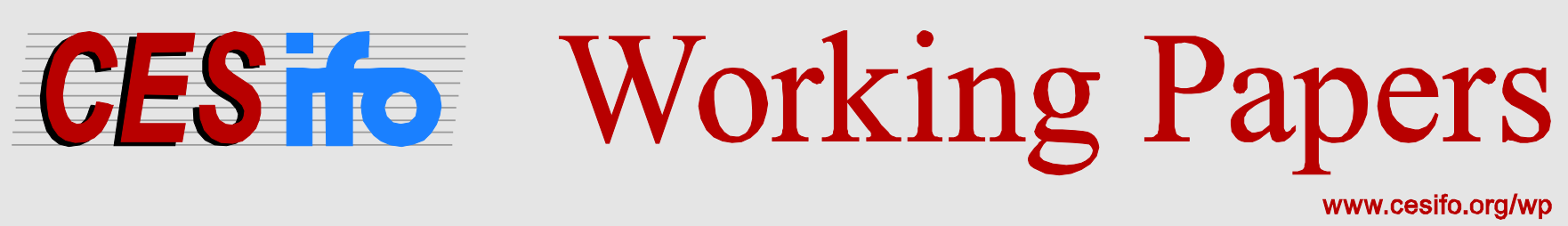

\title{
Political Institutions and Government Spending Behavior in Iran
}

\author{
Sajjad Faraji Dizaji \\ Mohammad Reza Farzanegan
}

CESIFO WORKING PAPER NO. 4620

CATEgORY 2: Public CHOICE

JANUARY 2014

An electronic version of the paper may be downloaded

- from the SSRN website:

- from the RePEc website:

- from the CESifo website:

wWw.SSRN.com

www.RePEc.org

www.CESifo-group.org/wp

\section{CESifo}




\title{
Political Institutions and Government Spending Behavior in Iran
}

\begin{abstract}
This study examines how quality of political institutions affects the distribution of government budget and how development of government spending in major sections shapes the political institutions in Iran. This question has become especially important due to recent international sanctions, aiming to change the political behavior of Iran. We use the impulse response functions (IRF) and variance decomposition analysis (VDC) on the basis of Vector Autoregressive (VAR) model with annual data from 1960 to 2006. Our results show the importance of political institutions in patronage and public goods provision spending in Iran. The results imply that a shock in positive changes of democratic quality of institutions leads to negative and statistically significant response of military spending and positive and statistically significant response of education expenditures in short term. If sanctions are successful to change the political behavior of Iran in short run (Dizaji and Bergeijk, 2013), then one can also expect to see a reduction in allocated budget for military in Iran.
\end{abstract}

JEL-Code: H110, H410, P160, O530, O430.

Keywords: political institutions, government spending, Iran, VAR modelling, sanctions.

Sajjad Faraji Dizaji

Tarbiat Modares University

Teheran / Iran

s_dizaji@modares.ac.ir
Mohammad Reza Farzanegan* CNMS, Middle East Economics Department Philipps University of Marburg

Deutschhausstrasse 12

Germany - 35032 Marburg farzanegan@uni-marburg.de

*corresponding author

January 8, 2014 


\section{1- Introduction}

Our goal in this study is to examine how quality of political institutions in Iran has shaped behavior of the state towards patronage and public goods provision. Our approach to this nexus has been also additionally motivated by recent significant international sanctions to change the political behavior of Iranian government. Our main results show that a shock in positive changes of quality of political institutions leads to negative and statistically significant response of military spending, as a proxy of patronage in economics, and positive and statistically significant response of education expenditures, as an indicator of public goods provision, in short term.

Autocracies are shown to be persistent despite of their long run negative economic development consequences $^{1}$. For example, Deacon (2009) suggests that almost $68 \%$ of countries in the last half of $20^{\text {th }}$ century were governed by dictators and one third of them remained in this status until 2000.

In autocracies a small dominant coalition rules the rest of population. Dictator needs to buy the royalty of this limited coalition by allocating more budget and economic opportunities. Military lobby has been one of the main drivers of persistency of autocracies in history. By contrast, democracies represent a wide cross section of society and thus need to provide more public goods in a form of education and health rather than securing economic benefits of selected group of citizens in return for their political royalty. It is also not only the issue of quantity of spending allocation but also quality of spending will be different in autocracy compared with democracy. Deacon and Sasha (2006) show the poor quality of public services under autocracies.

In our study, we focus on the case of Iran to quantify the magnitude and significance of political institutions in government spending behavior. Iran provides an interesting context for this

\footnotetext{
${ }^{1}$ For long rune negative economic development effects of autocracies see Olson (1993) in which he refers to the lack of individual property rights and weak enforcement of contracts in such societies.
} 
analysis: It has experienced different political regimes, the autocracy of Pahlavi in which the Shah was the most powerful political figure and the post-1979 Islamic revolution which deals with factionalized semi-democracy (see Bjorvatn, Farzanegan and Schneider, 2013 for growth effects of factional politics in Iran).

Military affiliated groups were the central supporter of the autocracy of Shah. Under his rule, the share of government spending for military in real prices in total government spending was $33 \%$. The Islamic republic was established on popular support of middle and lower income classes. It represents a wider range of population than the former regime. Average military spending (as \% of total government spending) in post 1979 revolution was 29\%. Excluding the Iraq-Iran war period (1980-1988), this share reduces to 25\% (CBI, 2013). The opportunity costs of patronage behavior is high: there is negative and statistically significant (at $5 \%$ level of significance) correlation between military spending with education spending $(-0.46)$, health spending $(-0.30)$, and cultural spending (-0.31) from 1959-2006.

Another motivating reason for our analysis is recent multilateral energy and financial sanctions which aim to change the political attitudes of Iranian government by affecting main financial source of revenues, i.e., oil export. Indeed, one of the main funding channels of patronage and transfer policies in Iran is petrodollars. Literature and historical evidences show that dictators in oil rich economies depend on redistribution of oil rents and if it does not work they stick to repression policies. Oil revenue is key factor for both choices. For the repression of course they need well-established military and security apparatus (Wintrobe 2001 and 2012; Acemoglu et al., 2010).

There is an increasing attention in literature and policy discussions on the effectiveness of sanctions for changing the political approaches of Iranian government in different fields such as 
nuclear program, military projects and human rights. In a recent study, Dizaji and Bergeijk (2013) show that the sanctions can affect the Iranian key macroeconomic variables, improving political openness in short term. As a result of energy and banking sanctions, Iran oil production shows a significant reduction of 1 million barrels per day (mbbl/d): from about $4 \mathrm{mbbl} / \mathrm{d}$ in 20052011 to approximately $3 \mathrm{mbbl} / \mathrm{d}$ during 2012-2013. Given the average oil price per barrel in 2012 of $\$ 111.67$ (BP, 2013), the oil related sanctions has led to a daily loss of $\$ 111,670,000$ and in other words an annual loss of about $\$ 41$ billion.

Figure 1 shows the trend of monthly oil production in Iran since 2005. The significant drop of oil supply since 2011 as a result of sanctions is evident. Reducing oil supply is going also to shape the rest of the economy due to high dependence of national economy to oil industry. The share of oil revenues in GDP shows a continuous increase in Iranian government budget since revolution of 1979 from 11\% during Iran-Iraq war (1980-1988) to 21\% during Ahmadinejad's government (2006-2012). Dizaji (2012) investigates the dynamic relationship between government revenues and government expenditures in Iran. His findings show that a strong causality is running from oil revenues (\% of GDP) to government total expenditures (\% of GDP). This indicates that sanctions which damage the oil revenues can strongly affect the Iranian government expenditures and this in turn may affect the political behavior of the government. More critically, the foreign exchange reserves of Iran are highly dependent on oil exports. This is in spite of all efforts to increase the size of non-oil exports in post-revolution period. On average, during the Ahmadinejad state the share of oil exports in total exports was $74 \%$. Negative shocks to the main source of government revenues following a wave of sanctions proved to be highly inflationary with negative consequences for industrial production (Farzanegan and Markwardt, 2009). Inflation rate shows a significant increase from $7 \%$ at last months of 2009 to more than $40 \%$ in 
July 2013. Industrial production has decreased by almost $\$ 2$ billion from $\$ 7$ billion in 2011 to $\$ 5$ billion at the end of 2012 (GEM, 2013).

Figure 1. Monthly Oil Production of Iran

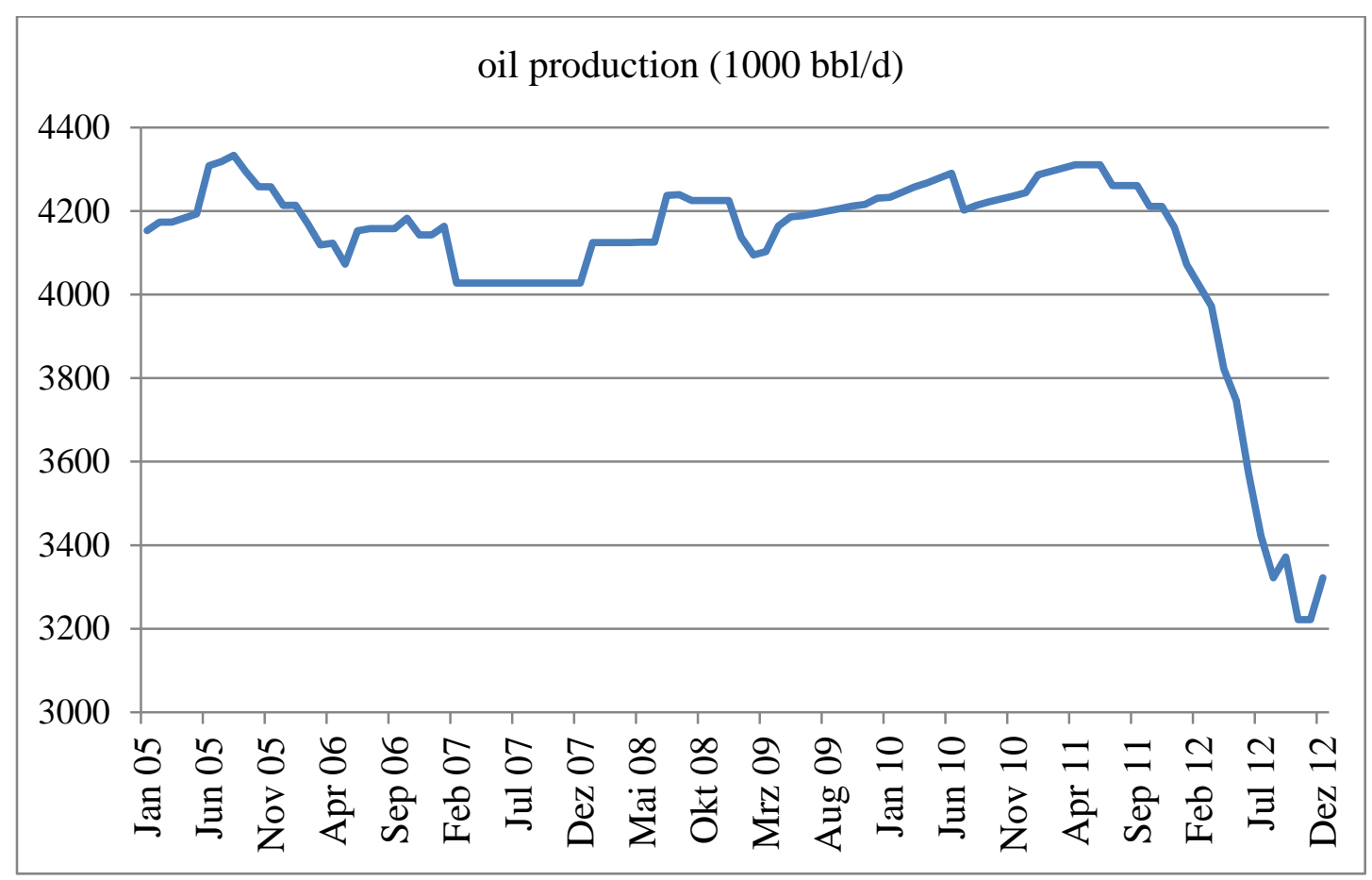

Source: EIA (2013)

Farzanegan (2011) was one of the first studies which investigated how sanctions (via negative changes of oil rents) affect the dynamic of government spending in Iran. His study shows that military and security spending of Iran has a significant and negative response to decreasing oil revenues following energy and banking sanctions. In a subsequent paper, he also shows that there is a significant interaction between economic growth and military spending in Iran. Sanction by reducing military spending also lead to lower economic growth in Iran due to strong linkages between military and economy in Iran (Farzanegan, 2012). A key question of sanction designers is if such restrictions which reflect itself in the allocation of government budget in different fields bring any significant change in the political institutions of Iran. In our paper, we evaluate the government spending-political institutions nexus in Iran. 
Our paper adds to the literature by examining the dynamic interaction between different categories of government spending and political institutions in Iran. How shocks in different categories of government spending (military, disciplinary, and education among others) transfer and reflect in political institutions. In addition, we also analyze the response of government spending in each category to a shock in political institutions.

The main results show that shocks to positive changes of democratic institution indicator reflects itself in negative response of military spending and positive response of education spending which both are statistically significant. Furthermore, a one standard deviation increasing shock in military spending lead to negative and significant response of democracy indicator in Iran.

This paper is structured as follows: In Section 2 we present a review of literature on government spending and democracy nexus. In Section 3 we describe the data we use, and explain empirical methodology and results. In Section 4, we conclude with a summary and discussion.

\section{2- Literature review}

A large part of literature examines relation between political institutions and economic growth (Helliwell 1994; Barro, 1996; Landman, 1999). A higher level of economic well-being which entails higher human capital and urbanization would be necessary for boosting democracy (Lipset, 1959; Boix, 2003; Acemoglu and Robinson, 2006). Stable democracies are also likely to promote economic liberalizations and reforms, which in turn would have a positive effect on the overall economic performance (Persson and Tabellini, 2007). In fact, democratization allows low-income groups to take part in the political process and, as a consequence, should be conductive to policies that favor these groups.

However, literature is not conclusive about positive income effects of democratic institutions. Tavares and Wacziarg (2001) find that democracy has a moderately negative effect on economic 
growth. They suggest that democracy fosters economic growth by improving the human capital and lowering the income inequality. However, it also reduces the rate of physical capital accumulation and increases government consumption, hindering economic growth. Barro (1996) explains that even though at low levels of democracy, increases in the degree of democracy foster economic growth, further increases reduce it after a moderate amount of democracy has been achieved.

In sum, it seems that the net effect of democracy on economic growth is ambiguous. We believe that focusing on the possible channels which link the political variables to economic growth can be helpful in identifying the nature of the political institutions-growth nexus. One of the important channels in this nexus is the level of government spending and its different categories. Moreover, Sasmal (2011) suggests that the government in a democratic setup of the developing world is not always guided by the objective of maximization of growth. Instead, it may manipulate fiscal instruments to capitalize on its political gain so that it can retain power.

Government expenditure design and public spending programs are at the core of economic policy. Although the relationships among regime type, economic growth, and income distribution are extensively explored in the literature, there is little work devoted to investigating the impact of political system characteristics on the different categories of government expenditures (Brown and Hunter, 1999; Kaufman and Segura-Ubiergo, 2001).

Some of the existing studies consider the relationship between democracy and the total amount of the public sector. Aidt and Eterovic (2011) suggest that political competition appears to be negatively correlated with the government size, while the opposite is true for political participation. Moreover, Martin and Plumper (2003), Hausken et al. (2004) and Aidt et al. (2010) find a U-shaped relationship between democracy and public spending. They suggest that for low 
levels of democracy public spending is high to meet the demands of elites, while for high levels of democracy the usual median voter's model prediction applies and public spending is high due to popular demand of public goods. For medium levels of democracy, however, none of these pressures is active and government spending is at its minimum.

Funk and Gathmann (2011) estimate the effect of direct democracy on government spending in Swiss cantons. Their findings show that both mandatory budget referendum and voter initiative reduce canton spending, but the constraining effects of both institutions are more moderate than suggested by previous cross-sectional studies. Their results also show that direct democratic institutions at the canton level play a limited role for the vertical structure of government. They measure spending centralization as (CantonExp/Canton+LocalExp). Neither the budget referendum nor the voter initiative has effect on local spending or decentralization. They suggest that the positive correlation in the raw data and earlier studies is driven by time-invariant omitted variables, such as differential preferences for spending at the local level or other political institutions that govern the division of labor between canton and local governments.

Some other studies have tried to focus on the relationship between democracy and government expenditure in a special area such as military, education, and health. Expenditures on social security and welfare, health, and education are an essential part of what governments do to enhance the quality of life of their citizens. Regarding the military expenditures it is generally believed that as the degree of democracy increases in a country, the military expenditures will decrease. Democratic states are more likely to be at peace and less prone to become involved in international conflicts (James et al. 1999, 2000; Oneal and Russet 1997; Lebovic 2001). Democratic states resolve their domestic conflicts by compromise and nonviolent means, providing an environment where international conflicts between democratic states are also 
settled peacefully. James et al. (1999) suggest that two democratic states are more likely to have peaceful relations. They develop a simultaneous two-equation system, showing that peace and democracy foster each other during the cold war period. According to their findings the dyadic democracy-peace nexus generally was not statistically significant but the alternative, peace causing democracy, was much stronger. Lebovic (2001) shows that the level of democracy has a significant positive effect on the size of non-military relative to military budgets. Yildirim and Sezgin (2005) using cross section and panel data for 92 countries from 1987 to1997 find an inverse relationship between the level of democracy and military spending.

There are few studies that investigate the relationship between the characteristics of political systems and education outputs or outcomes. Saint-Paul and Verdier (1993) present a model where public education constitutes an instrument of inter-generational redistribution and also creates human capital which promotes long-run growth by raising the human capital of successive generations. In their set-up, democratization rises spending on public education and increases both growth and equalization of income. Wacziarg (2001) considers a human-capital augmented Solow model where saving in human capital is a public choice modeled in a medianvoter setting. Each agent seeks to maximize steady-state level of consumption and a voter's ideal saving rate depends in part on the voter's relative position in the income distribution profile. A decrease in decisive agent's income relative to mean (as in the case of greater democracy) is associated with two counter-veiling effects on the level of ideal saving rate in human capital. On the one hand, a poorer agent would want greater human capital as it represents greater redistribution and the voter gets a bigger share of the pie but, on the other hand, greater redistribution distorts the economy which affects the steady state level of income and hence may reduce the size of the pie. In Wacziarg's model, the dominant effect depends on the saving rate 
in physical capital relative to population growth. When saving in physical capital is high relative to population growth, greater democracy tends to increase human capital accumulation. Brown and Hunter (2004), using time-series cross-sectional analysis, examine the relationship between democracy and education spending in 17 Latin American countries between 1980 and 1997. They assess the impact that democracy has on the distribution of resources between different levels of schooling and on total spending on education. Specifically, they test whether democratic governments allocate a greater share of resources to primary education, the level that benefits the largest segment of the electorate and that is most critical for human capital formation in developing countries. They show that democracies devote a higher percentage of their educational resources to primary education.

There is a small literature that looks at the relationship between health expenditures and democracy in cross-country data. Lake and Baum (2001) relate democracy to a variety of public health interventions. Franco et al. (2004) report a positive correlation between life expectancy and democracy (see also Govin-daraj and Rannan-Eliya, 1994). Besley and Kudamatsu (2006) suggest that there are three main theoretical differences between democracies and autocracies regarding health issues. The first relates to representation. Health indicators will improve if public health is more of a priority for groups who dominate under a democracy compared to those who gain political influence in an autocracy. The second is that democracies demand accountability to a broad set of citizens at regular intervals whereas autocrats are accountable only to a smaller group such as the military. This view also predicts that greater attention will be paid to health issues in democracies since failure to do so should result in leaders being removed from office -this link being weaker in autocracies. A third difference between democracies and autocracies concerns the process of political selection with democracies having stronger 
mechanisms for selecting competent and honest leaders to implement policy. To the extent that health interventions are supported by skilled and incorruptible political leaders, then democracies should lead to better health outcomes than autocracies.

A number of the studies have tried to include different of categories of government expenditures in considering the relationship between spending behavior and democracy to make a comparison among the effects of democracy on different categories of government expenditures. In particular, Habibi (1994) suggests that more democratic countries tend to spend more on social programs and less on military, while Boix (2001 and 2003) finds that a significant share of the public sector depends on the political (democratic) regime in place, which also interacts with the distribution of income, citizens' preferences and economic conditions.

Snyder and Yackovlev (2000) present evidence from a panel of 19 Latin American and Caribbean countries for the period 1970-1996. They disaggregate social spending into education and health and other components and explain changes in spending as function of the level of political and program specific variables. Using a binary indicator for democratic regimes they find that social spending (particularly education and health) grows more under democratic rule. They also find that more pro-poor components of social spending (which they take to be primary and secondary education spending) are relatively more insulated from economic shocks.

Vergne (2009), using data for 42 developing countries from 1975 to 2001, finds evidence of electoral impacts on the allocation of public expenditures. She considers three spending variables, namely current expenditures, capital expenditures and expenditures in infrastructure, expressed as a share of total public spending. The results show that election-year public spending shifts towards more visible current expenditures, in particular wages and subsidies, and away from capital expenditures. Furthermore, her findings suggest that electoral impacts on the 
allocation of public spending are likely to endure, even though countries gain experience in electoral politics. The results show neither a significant nor systematic electoral impacts on the share of infrastructure spending.

Profeta et al. (2012), focusing on three geographical areas (Asia, Latin America and new EU members) explore the relation between political variables and tax revenue, public spending and their structure for the period 1990-2005. Their findings cast some doubt on the exact public policy channels through which political institutions affect economic development. They refer to two different variables for democracy, the political strength of democratic institutions, and the protection of civil liberties and estimates three sets of models: (i) cross-country pooled OLS regressions with region fixed effects, (ii) country fixed effects regressions and (iii) region specific regressions with country fixed effects. They find several significant relationships between political variables and tax sources only when they run pooled OLS regressions, while they are no longer significant when adopting a more demanding specification with country fixed effects. Regarding to the government expenditures, in the pooled OLS model they find a positive and significant correlation between the democracy index and expenditure both in education and in public order. But these findings are not robust to the inclusion of country fixed effects.

However when focusing on new EU members, which represent more mature democracies, total government spending, as well as expenditure in health and in social protection, turns out to be positively correlated with the civil liberties index and negatively with the democracy one. They explain that, although socialist countries have reacted differently to the transition, a common feature of many new EU members has been the dramatic decrease of government size during this period. They argue that the general lack of significant correlations within a country fixed effects specification might be due to the presence of heterogeneity across world areas. 
Our brief literature review shows that although cross-country regression's results are mostly consistent and in line with theoretical predictions, however, cross-country studies are known to be subject to criticism, since the correlations may depend on unobservable country-specific characteristics. Therefore, examining single country studies with focusing on the specific characteristics of those countries can be more helpful. Moreover, the political economy analysis of public outlays should focus specifically on the composition of expenditures, since different public expenditures tend to have a different impact on various economic and political outcomes (see Aidt et al., 2006 and Aidt and Jensen, 2009a).

We examine the effects of political variables on different categories of Iranian government expenditures and vice versa. Recently some studies have been interested in analyzing the political behavior of Iranian government and its spending characteristics. In an attempt to model the response of Iranian government budget to energy sanction, Farzanegan (2011) applies Vector Autoregressive (VAR) models. Using historical data from 1959 to 2007, he shows that Iranian military and security spending are highly responsive to asymmetric oil revenues shocks. Social spending such as education and health react in an insignificant magnitude to such oil shocks. Using an asymmetric definition of oil and gas rents per capita, he finds that a one standard deviation absolute increase in negative changes of energy rents causes a significant and negative response on the side of military and domestic security spending.

Dizaji and Bergeijk (2013) consider the effects of economic sanctions on both economic and political variables of Iran. They theoretically and empirically argue that sanctions have a higher probability of success in the early phase and a lower probability of success in the long run. Using VAR models they find significant impacts of economic sanctions both on key economic variables (government consumption, imports, investment, income) and on two indicators of the 
political system (the Polity variable that describes shifts in the autocracy-democracy dimension and the Vanhanen Index of democratization that describes political competition and participation). Their results indicate that a reduction of oil and gas rents creates economic costs that act as incentives to move towards a more democratic setting. However, this effect is only significant in the first two years and turns negative after six to seven years, as adjustment of economic structures mitigates the economic and political impact of the sanctions.

\section{3- Research design}

\section{Data description}

To examine the dynamic interconnections between political institutions and the structure of the Iranian government spending, we use the following variables: Military expenditures (ldefetot), public order and disciplinary expenditures (ldiciptot), education expenditures (ledutot), health and medical services expenditures (lhealthtot), and cultural and recreational services expenditures (lculttot) from the Central Bank of Iran (CBI) online database in constant 1997 prices. These variables are expressed as their share in total government expenditures and in logarithmic form. Moreover, we use the Polity2 index as a widely used measure of political institutions (Marshall et al., 2012). This variable describes combinations of autocratic and democratic characteristics of the institutions of government (Marshall et al., 2012). Subtracting the autocracy score from the democracy score yields a summary measure Polity2. This index is from -10 (full autocracy) to 10 (full democracy). The higher scores means a more open and competitive political system. For robustness tests we also use the objective democracy indicator of Vanhannen. 


\section{Methodology}

We use the VAR model to estimate the interrelationships among our variables. The VAR provides a multivariate framework relating changes in a particular variable to changes in its own lags and to changes in (the lags of) other variables:

$$
y_{t}=A_{1} y_{t-1}+\cdots+A_{p} y_{t-p}+B x_{t}+\varepsilon_{t}
$$

Where $y_{t}$ is a vector of $\mathrm{k}$ endogenous variables, $x_{t}$ is a vector of $\mathrm{d}$ exogenous variables, $A_{1}, \ldots$, $\mathrm{A}_{\mathrm{p}}$ and $\mathrm{B}$ are matrices of coefficients to be estimated, and $\varepsilon_{t}$ is a vector of innovations that may be contemporaneously correlated but are uncorrelated both with their own lagged values and with all of the right-hand side variables.

We define the vector of exogenous variables as $x_{t}=$ [constant, $\left.D_{1}, D_{2}\right]$, where $D_{1}$ and $D_{2}$ are dummy variables capturing the 1979 Islamic Revolution and the Iran-Iraq war (1980-88), respectively. Since only lagged values of the endogenous variables appear on the right hand side of the equation, simultaneity is not an issue and OLS yields consistent estimates.

We use an unrestricted VAR models in levels. Firstly, structural VAR models are 'very often misspecified' (Tijerina-Guajardo and Pagan, 2003). Secondly, the Phillips-Perron and ADF unit root tests indicate that all variables are I(1) (see Table 1$)^{2}$. Since all the variables are nonstationary but cointegrated, differencing leads to loss of long run information. Sims (1980), Sims, Stock and Watson (1990), Doan (2000) and Fuller $(1976)^{3}$ have argued against differencing. After all, in this study we are interested in impulse response functions rather than interpreting each coefficient of the VAR model (see also Farzanegan and Markwardt, 2009, Farzanegan, 2011 and Dizaji and Bergeijk, 2013 for the similar approach).

\footnotetext{
${ }^{2}$ These tests include a constant but not a time trend, as recommended by Dickey and Fuller (1979).

${ }^{3}$ Fuller (1976) has also shown that differencing the data may not produce any gain so far as the asymptotic efficiency of the VAR is concerned even if it is appropriate.
} 
Thirdly, in the short term, which is especially important in our analysis, an unrestricted VAR performs better than a cointegrated VAR or Vector Error Correction Model. ${ }^{4}$

In the standard VAR, disturbances are generally characterized by contemporaneous correlations which it causes the response of the system to an innovation in one of the variables be the response of all those variables that are contemporaneously correlated with it. However, this contemporaneous correlation is purged by the Cholesky orthogonalization procedure.

The main applied tools in the VAR models estimation are the impulse response functions (IRFs) and the variance decomposition analyses (VDC). The dynamic response of macroeconomic variables to innovations in a particular variable can be traced out using the simulated responses of the estimated VAR system (IRF). Thus, the IRF allows us to examine the dynamic effects of shocks to a particular variable (for example democracy) on the different categories of government expenditures. Through IRF we can observe the magnitude and statistical significance of such responses to one standard deviation increase in democracy related variable error (see Stock and Watson, 2001 for more details on IRF).

An examination of the entire system is studied by analyzing the variance decomposition of the system. Variance decomposition assigns the variance of forecast errors in a given variable to self-shocks, as well as those of the other variables in the VAR. The Choleski decomposition method is adopted, in order to construct the variance decompositions.

\footnotetext{
${ }^{4}$ Naka and Tufte (1997) demonstrate that the loss of efficiency from VAR estimation is not critical for the short horizon. Engle and Yoo (1987), Clements and Hendry (1995) and Hoffman and Rasche (1996) show that an unrestricted VAR is superior in terms of forecast variance to a restricted VEC model on short horizons.
} 
Table 1

ADF and Phillips-Perron unit root tests

\begin{tabular}{llllc}
\hline \hline Variable & \multicolumn{2}{c}{ ADF } & & Phillips-Perron \\
\hline & Level & $1^{\text {st }}$ diff & Level & $1^{\text {st }}$ diff \\
lhealthtot & -1.60 & $-5.49^{* * *}$ & -1.66 & $-5.37^{* * *}$ \\
ldefetot & $-2.76^{*}$ & $-4.39^{* * *}$ & -2.05 & $-4.06^{* * *}$ \\
ldiciptot & -2.06 & $-6.10^{* * *}$ & -2.11 & $-6.07^{* * *}$ \\
ledutot & -1.61 & $-5.12^{* * *}$ & -1.82 & $-4.99^{* * *}$ \\
lculttot & -2.27 & $-5.25^{* * *}$ & -2.31 & $-6.44^{* * *}$ \\
Polity2 & -1.99 & $-6.86^{* * *}$ & -2.01 & $-6.89^{* * *}$ \\
Critical Value 1\% & -3.58 & -3.59 & -3.58 & -3.58 \\
Critical Value 5\% & -2.93 & -2.93 & -2.93 & -2.93 \\
\hline \hline
\end{tabular}

***: Null hypothesis rejection at $1 \% *$ : Null hypothesis rejection at $10 \%$

A vector of variables integrated of order one can be cointegrated if there exists linear combination of the variables, which are stationary. To determine the number of cointegrating vectors we use the approach of Johansen and Juselius (1990) and results are shown in Table 2.

The test statistics indicate that the hypothesis of no cointegration among the variables can be rejected for Iran. The results reveal that at least three cointegrating vectors exist among the variables of interest.

\section{Table 2}

Tests for Cointegration

\begin{tabular}{lllll}
\hline \hline & \multicolumn{2}{c}{ Maximum eigenvalue statistic } & \multicolumn{2}{c}{ Trace statistic } \\
\hline Hypothesized No. of & Max-Eigen & 0.05 Critical & Trace & 0.05 Critical \\
CE(s) & Statistic & Value & Statistic & Value \\
\hline None & $60.45^{*}$ & 40.07 & $149.28^{*}$ & 95.75 \\
At most1 & $40.28^{*}$ & 33.87 & $88.74^{*}$ & 69.81 \\
At most2 & $28.58^{*}$ & 27.58 & $48.46^{*}$ & 47.85 \\
At most3 & 11.38 & 21.13 & 19.87 & 29.79 \\
At most4 & 8.46 & 14.26 & 8.49 & 15.49 \\
At most5 & 0.03 & 3.84 & 0.03 & 3.84 \\
\hline \hline
\end{tabular}

*: Max-eigenvalue test indicates 3 cointegrating eqn(s) at the 0.05 level. **: Trace test indicates 3 cointegrating eqn(s) at the 0.05 level 


\section{Empirical results}

We use a VAR model with six variables to examine the impact of political changes in Iran on the different categories of government expenditures.

In our unrestricted VAR model, the vector of endogenous variables is as follows:

$$
y_{t}=[\text { polity } 2, \text { health, military, disciplinary, education, culture }]
$$

This is our first choice as the Cholesky ordering in the VAR system. The first variable in a prespecified Cholesky ordering has an immediate impact on all other variables (different kinds of government spending) in the system, excluding the first variable and so on.

Health, military and disciplinary expenditures followed the first variable in the Cholesky ordering. Finally, education and cultural expenditures are categorized as the most endogenous variables in the VAR system. The Iranian government usually changes the share of these two latter costs to increase or maintain military, security, and health costs (Farzanegan, 2011).

Determining an optimum lag length for a VAR model is also very important. Economic theory usually does not provide any definite guidelines on the appropriate level of lag length in a VAR model. For finding the optimum lag we use information criteria such as LR, FPE (final prediction error), AIC (Akaike information criterion), SC (Schwarz information criterion), and HQ (Hannan-Quinn information criterion). We select the lag length of 2 on the basis of the LR, FPE, and AIC criteria and also with respect to stability and diagnostic tests.

\section{Impulse response functions}

In this study, the impulse response functions trace out the response of current and future values of different categories of the Iranian government expenditures (military, education, disciplinary, health, and cultural) to a one standard deviation increase in the current value of political related variable errors. The middle line in IRFs displays the response of different government 
expenditures to a one standard deviation shock in Polity2 variable. The dotted lines represent confidence bands at $95 \%$ confidence intervals. When the horizontal line in the IRFs falls between confidence bands, the impulse responses are not statistically significant. In other words, the null hypothesis of "no effects political variable" on the specific government expenditure cannot be rejected (Berument et al., 2010). The horizontal line in IRFs shows the time period (years) after the initial shock. The vertical line in IRFs shows the magnitude of response to shocks.

Figure 2 displays the impulse responses of different categories of the Iranian government expenditures to a one standard deviation shock in Polity2 for a period of 1960-2006. The Polity2 shock was identified on the basis of a standard Cholesky factorization, ordering Polity2 first followed by health, military, security, education and cultural expenditures (as\% of total expenditures and all variables in logarithmic form except for Polity2). We assume that health expenditures are rather sticky, so that they are not affected contemporaneously by other kinds of expenditures. After all, health related issues are one of the top priorities of most governments and they cannot be neglected easily. Military and disciplinary expenditures are also sticky but can still be adjusted more easily during peace time. In this view, the chosen ordering of the variables, has the most intuitive appeal and also produces reliable impulse responses (Farzanegan, 2011).

Figure 2 shows that the innovations to Polity2 are found to have statistically significant and negative effect on government military expenditures. The response of share of military expenditures is statistically significant for the first year after initial shock. The responses of Polity2, health expenditures, disciplinary expenditures and education expenditures to a one standard deviation increasing shock in Polity2 are positive and significant at least for 2 years 
after the initial shock. However the innovations to Polity2 have not significant effect on cultural expenditures.

Response to Cholesky One S.D. Innovations \pm 2 S.E.

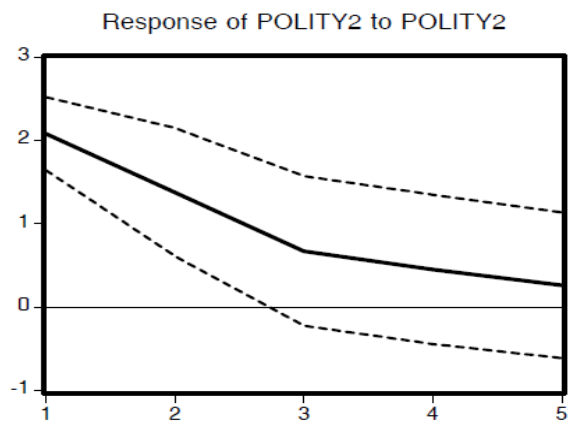

Response of LHEALTHTOT to POLITY2

Response of LDEFETOT to POLITY2

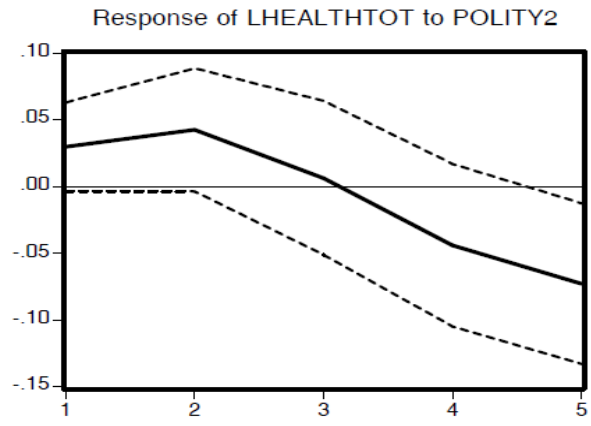

Response of LDICIPTOT to POLITY2
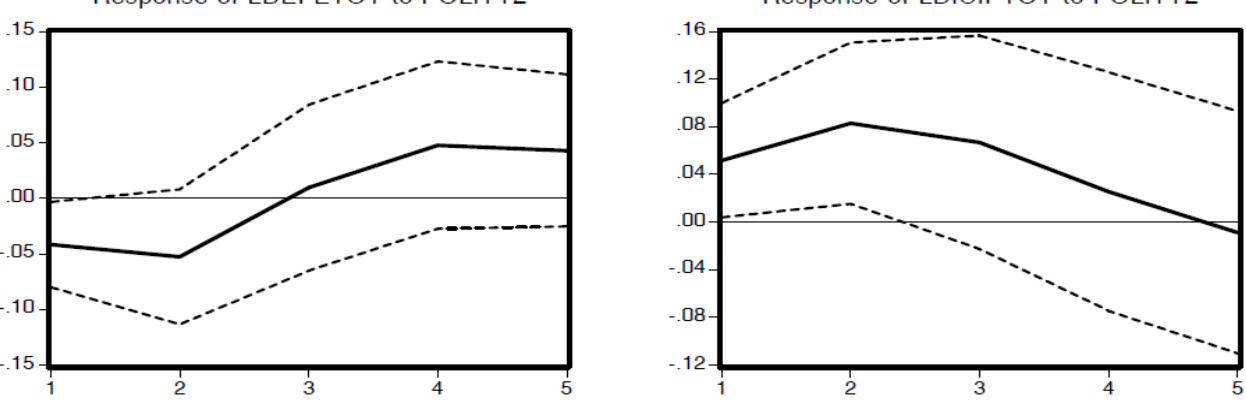

Response of LEDUTOT to POLITY2

Response of LCULTTOT to POLITY2
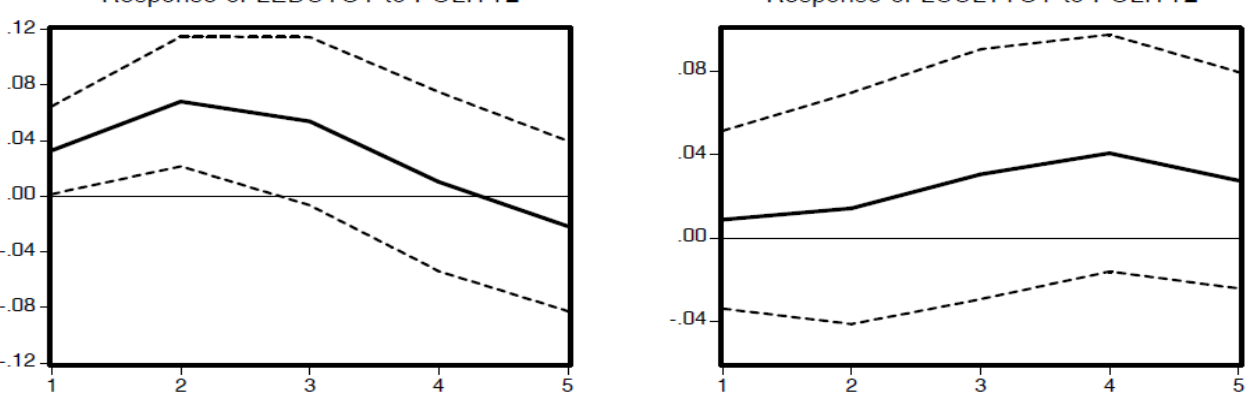

Fig 2.VAR responses to a shock in political variable (model with Polity2)

Taken together, these findings show that improvement in democratic situations will cause, on the one hand, initially negative and statistically significant effects on Iranian military expenditures and, on the other hand, initially positive and statistically significant effects on education, health and disciplinary expenditures. 
The previous studies about Iran (Dizaji and Begeijk, 2013) show that the sanctions on the Iranian oil industry perform initially significant and statistically positive effects on Iranian political situations in order to be more democratic. Combining the results of Dizaji and Bergeijk (2013) with the results of our study implies that economic sanctions cause positive effects on the indexes of democracy in Iran and this will perform negative effects on military expenditures and positive effects on government social expenditures such as disciplinary, health and education expenditures. Interestingly this findings are consistent with the results of Farzanegan's (2011) studies, who argues that increasing global pressure on the energy industry of Iran, which is the core element of very recent sanctions, may mitigate the expenditures of the government on military issues without hurting the government's other social functions significantly. However, as Dizaji and Bergeijk (2013) discuss these effects are only significant in the short run but the effects of sanctions in the long run are limited at best.

Also we have examined the diagnostic statistics of the estimated VAR model. For stability of our model Figure 3 shows the AR graph which reports the inverse roots of the characteristic AR polynomial. This figure shows that in the VAR model all roots have modulus less than one and lie inside the unit circle and the VAR model is stable.

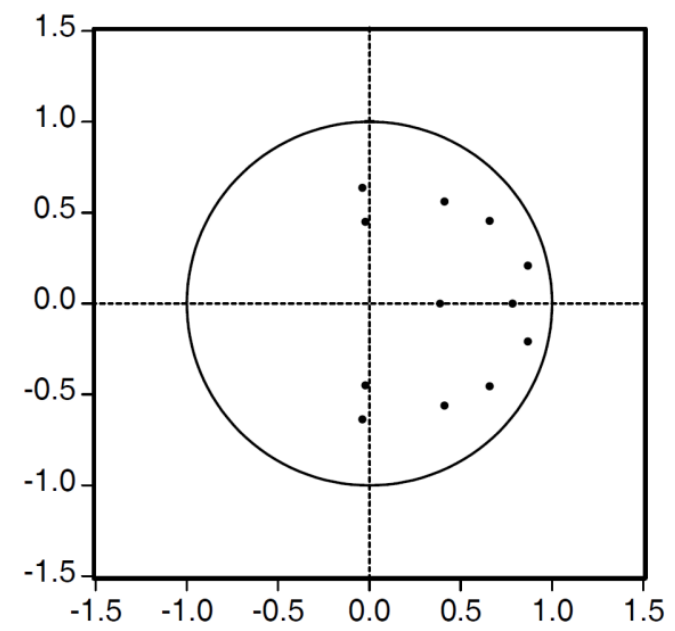

Fig 3. Inverse roots of AR Characteristic Polynomial 
Moreover the results of autocorrelation LM test in table 3 show lack of auto-correlation. All in all our diagnostic criteria show that our estimated VAR model which is a basis for the impulse response functions in Fig. 2 is stable and satisfactory.

Table 3: VAR residual Serial correlation LM test

\begin{tabular}{lll}
\hline \hline Lags & LM-Test & P-value \\
\hline 1 & 47.4 & 0.09 \\
2 & 34.2 & 0.55 \\
3 & 42.5 & 0.21 \\
4 & 23.3 & 0.94 \\
5 & 46.9 & 0.10 \\
6 & 35.3 & 0.50 \\
7 & 42.2 & 0.21 \\
8 & 35.3 & 0.49 \\
\hline \hline
\end{tabular}

Note: H0: no serial correlation at lag order h

\section{Variance decomposition}

We also examine the forecasting error variance decomposition to determine the proportion of the movements in the time series that are due to shocks in their own series as opposed to shocks in other variables. Table 4 shows that for almost all variables, the largest portion of variation is explained by their own trend in the first year. Hence at the start of the simulations the historical trend of each variable explains a large part of its own variation.

Polity2 shocks play an important role in explaining the variation of the other variables in the long run (Its contributions in explaining the shocks to ldefetot and ledutot are about 14 and 19 per cent in 10th year). The contribution of Polity2 shocks to government health expenditure shocks was about 10 per cent in the first year rising to about 26 per cent in the eighth year.

The big part of the variations in military expenditures is explained by itself in all years. However the shocks to Polity2 and disciplinary expenditures also affect the shocks to the military expenditures very significantly. As evidenced in table 4, shocks to cultural expenditures 
explained about 31 and 28 per cents of shocks to the education expenditures and disciplinary expenditures in the $10^{\text {th }}$ year. This implies that considerable causalities can exist from cultural expenditures to education expenditures and disciplinary expenditures.

Table 4

Variance decomposition

\begin{tabular}{|c|c|c|c|c|c|c|}
\hline & POLITY2 & $\overline{\text { LHEALTHTOT }}$ & LDEFETOT & LDICIPTOT & $\overline{\text { LEDUTOT }}$ & 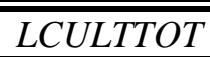 \\
\hline \multicolumn{7}{|c|}{ Variance decomposition of POLITY2 } \\
\hline 1 Year & 100 & 0.00 & 0.00 & 0.00 & 0.00 & 0.00 \\
\hline 2 Years & 87.50 & 1.64 & 0.04 & 5.33 & 5.47 & 0.00 \\
\hline 5 Years & 62.03 & 1.76 & 2.36 & 19.76 & 13.70 & 0.38 \\
\hline 8 Years & 52.16 & 1.81 & 3.86 & 20.06 & 21.62 & 0.48 \\
\hline 10 Years & 51.18 & 1.79 & 4.61 & 19.70 & 21.86 & 0.86 \\
\hline \multicolumn{7}{|c|}{ Variance decomposition of LHEALTHTOT } \\
\hline 1 Year & 6.79 & 93.21 & 0.00 & 0.00 & 0.00 & 0.00 \\
\hline 2 Years & 11.32 & 77.02 & 0.96 & 8.27 & 1.67 & 0.75 \\
\hline 5 Years & 20.47 & 43.86 & 0.93 & 18.63 & 1.75 & 14.36 \\
\hline 8 Years & 26.24 & 30.01 & 2.97 & 22.59 & 8.23 & 9.95 \\
\hline 10 Years & 22.78 & 26.13 & 4.51 & 22.67 & 15.08 & 8.83 \\
\hline \multicolumn{7}{|c|}{ Variance decomposition of LDEFETOT } \\
\hline 1 Year & 9.97 & 4.58 & 85.45 & 0.00 & 0.00 & 0.00 \\
\hline 2 Years & 11.09 & 4.08 & 80.16 & 2.99 & 1.13 & 0.53 \\
\hline 5 Years & 13.87 & 5.26 & 68.93 & 8.19 & 1.00 & 2.75 \\
\hline 8 Years & 13.79 & 6.87 & 54.25 & 15.59 & 4.61 & 4.90 \\
\hline 10 Years & 13.73 & 6.33 & 49.85 & 16.78 & 8.37 & 4.94 \\
\hline \multicolumn{7}{|c|}{ Variance decomposition of LDICIPTOT } \\
\hline 1 Year & 9.8 & 6.97 & 6.18 & 77.04 & 0.00 & 0.00 \\
\hline 2 Years & 18.30 & 3.68 & 5.20 & 62.50 & 0.87 & 9.45 \\
\hline 5 Years & 11.96 & 2.40 & 3.14 & 47.56 & 2.65 & 32.30 \\
\hline 8 Years & 10.65 & 5.01 & 2.83 & 48.79 & 2.77 & 29.95 \\
\hline 10 Years & 11.33 & 5.45 & 2.73 & 48.72 & 2.94 & 28.83 \\
\hline \multicolumn{7}{|c|}{ Variance decomposition of LEDUTOT } \\
\hline 1 Year & 9.26 & 14.03 & 2.89 & 8.84 & 64.98 & 0.00 \\
\hline 2 Years & 22.38 & 10.11 & 2.80 & 4.07 & 51.25 & 9.37 \\
\hline 5 Years & 19.50 & 7.66 & 1.81 & 6.69 & 33.70 & 30.64 \\
\hline 8 Years & 19.24 & 8.04 & 3.41 & 7.27 & 29.58 & 32.47 \\
\hline 10 Years & 18.60 & 8.56 & 4.00 & 7.99 & 29.48 & 31.37 \\
\hline \multicolumn{7}{|c|}{ Variance decomposition of LCULTTOT } \\
\hline 1 Year & 0.38 & 0.19 & 6.95 & 2.16 & 0.43 & 89.90 \\
\hline 2 Years & 0.87 & 3.03 & 4.77 & 1.56 & 1.66 & 88.11 \\
\hline 5 Years & 8.28 & 6.23 & 5.14 & 3.41 & 3.85 & 73.07 \\
\hline 8 Years & 9.30 & 6.83 & 6.70 & 4.79 & 10.33 & 62.05 \\
\hline 10 Years & 11.70 & 6.95 & 6.29 & 8.77 & 9.66 & 56.62 \\
\hline
\end{tabular}

Additionally, the results show that forecast errors in Polity2 other than its own variations are mostly due to variations in education expenditures, disciplinary expenditures and military 
expenditures respectively. This finding indicates that while political changes can affect the different categories of government expenditures specially education and military expenditures, also these kind of government expenditures have a considerable role in determining the quality of political institutions in Iran. In other words probably there are bidirectional causalities between Polity2 and education expenditures and also Polity2 and military expenditures.

\section{Robustness analyses}

\section{Generalized impulse responses}

Ordering of variables in the VAR system is important in order to calculate the IRFs and VDC analyses. Different ordering may result in different IRF results. In order to avoid the difficulties of identifying orthogonal shocks in VAR models, Pesaran and Shin (1998) introduced Generalized Impulse Responses (GIR). The GIR functions construct an orthogonal set of innovations that does not depend on the VAR ordering. For comparison, we calculate the generalized impulse responses of the different compositions of government spending to total government spending ratio to a one standard deviation shock in Polity2. The responses are similar to those which we obtained using Cholesky one standard innovation ${ }^{5}$.

Alternative definition for quality of political institutions variable (Vanhenen index)

We use also an alternative institutional quality indicator called Vanhanen index (VI). The Vanhanen index of democratization is defined as the product of two underlying indices for political competition and political participation (Vanhanen, 2011). Since considering the effects of political changes on the different categories of the government expenditures is a key issue of our analysis, it is important Polity2 and VI measures do not only differ conceptually, but that

\footnotetext{
${ }^{5}$ Since the GIR results are identical to those obtained by the Cholesky ordering, we have not reported them here. They are available upon request.
} 
their measurement also differs (Polity2 scores are subjective/judgmental while Vanhanen deploys numerical voting records). Consequently, the two indicators show different patterns of variation. The Vanhanen index is taken directly from the Finnish Social Science Data Archive (Vanhanen, 2011).

Response to Cholesky One S.D. Innovations \pm 2 S.E.
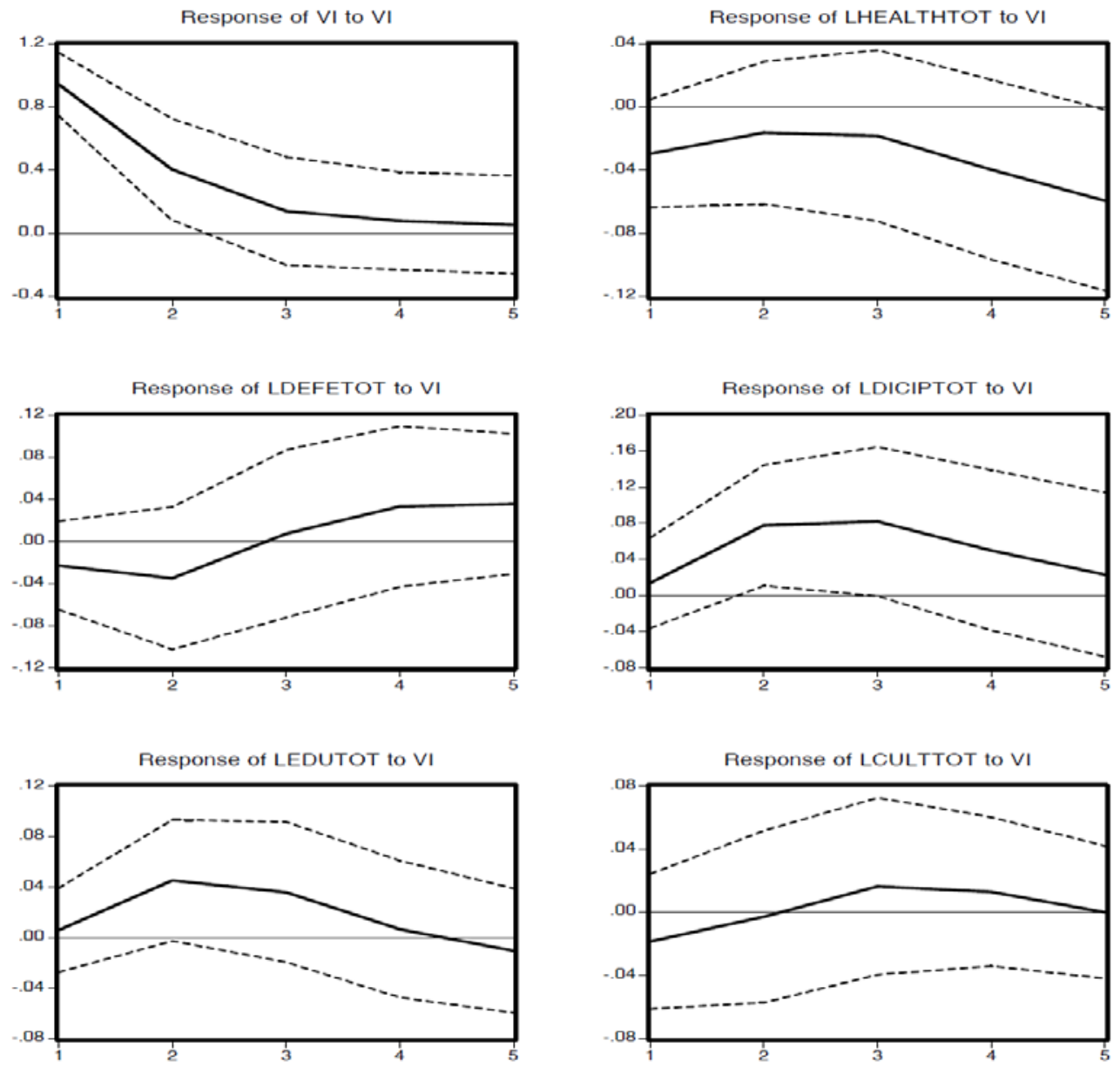

Fig 4.VAR responses to a shock in political variable (model with Vanhanen index) For this purpose we re-estimate the VAR model using the same Cholesky ordering (with Vanhanen index instead of Polity2) as in previous analysis. Considering the different lag criteria, we use 2 lags as the optimum number of lags in our analysis. We also control for the exogenous shocks of the Islamic revolution and the war period with Iraq. The VAR stability condition test 
(Roots of Characteristic Polynomial) indicates that the VAR satisfies the stability condition. The impulse response analysis, using Vanhanen index as a shock variable is presented in Fig. 4.

Looking at Fig 4 shows that although the shocks to Vanhanen index cause significant effects on the changes in the share of disciplinary expenditures (during the second and third years after initial shock), but their contributions in explaining the shocks to the other categories of government expenditures are not significant.

Response to Cholesky One S.D. Innovations \pm 2 S.E.
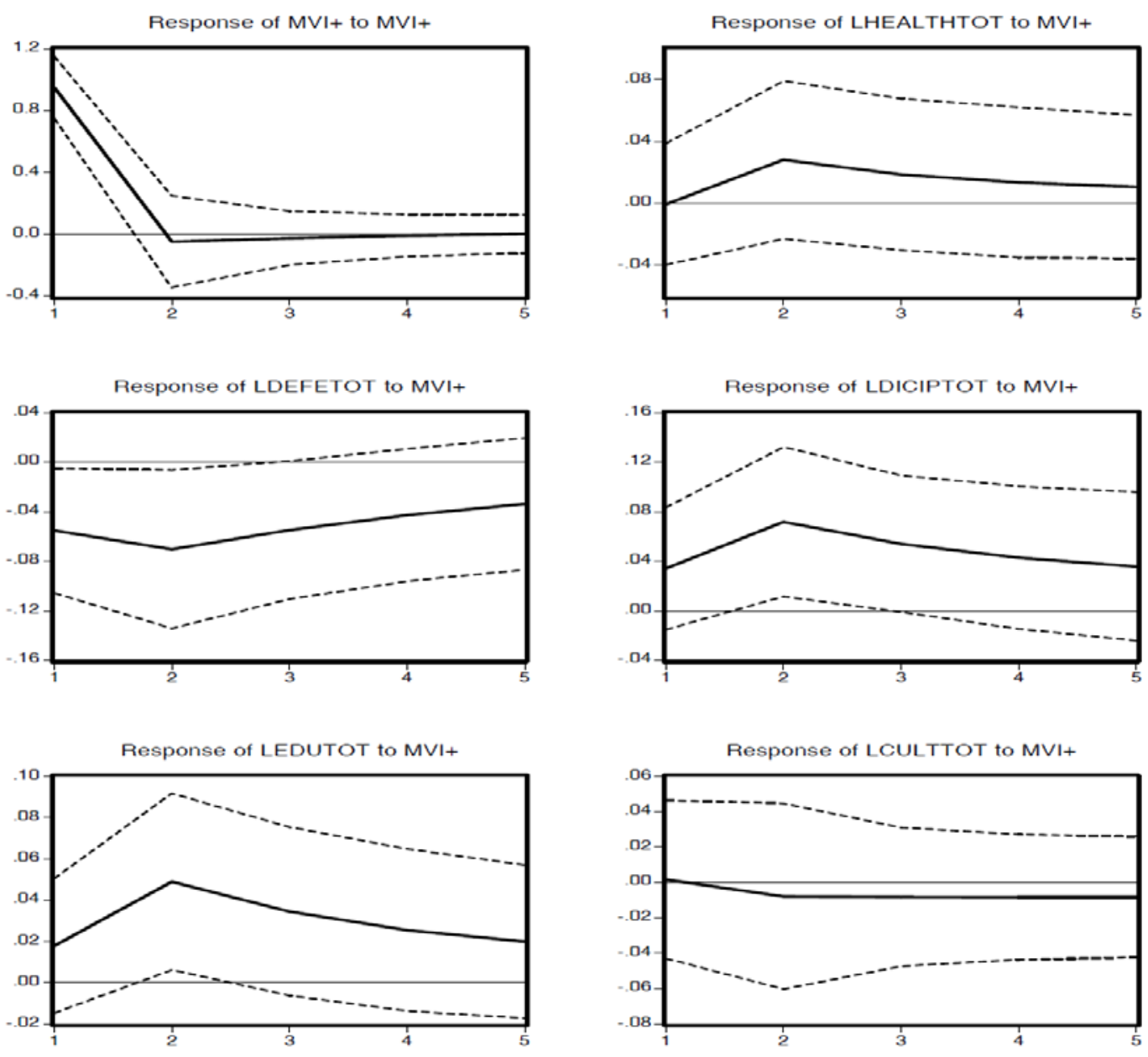

Fig.5. Impulse responses to one standard deviation shock in positive changes of Vanhanen index $(\mathrm{MVI}+)$ 
Possibly, this is because we should make differences between positive shocks and negative shocks as it has been discussed in the literature of asymmetric shocks by Mork (1989) and Hamilton (1996).

In line with Mork's work which has proposed an asymmetric definition of oil prices in order to distinguish between positive and negative oil price shocks, we define the positive and negative changes in Vanhanen index (VI) as follows:

$\mathrm{MVI}_{\mathrm{t}}+=\max \left(0,\left(\mathrm{VI}_{\mathrm{t}}-\mathrm{VI}_{\mathrm{t}-1}\right)\right)$

$\mathrm{MVI}_{\mathrm{t}^{-}}=\min \left(0,\left(\mathrm{VI}_{\mathrm{t}^{-}}-\mathrm{VI}_{\mathrm{t}-1}\right)\right)$

where $\mathrm{VI}_{\mathrm{t}}$ is Vanhenen index in time t. For more comprehensive details on asymmetric shocks see Mork (1994).

Fig. 5 shows IRFs based on one standard deviation shock to positive changes in Vanhanen index. We use 1 lag of endogenous variables on the basis of different lag criteria, controlling for revolution and war with Iraq exogenous shocks. The results of stability test on our VAR model are also satisfactory ${ }^{6}$.

The response of share of military expenditures is clearly both negative and significant and lasted over the first three years. This confirms that improvement in democratic characteristics decreases the Iranian government expenditures on military issues. Finally the response of the share of the education expenditures to positive changes in Vanhanen index is clearly positive till the end of the period but it is only significant in the second year after the initial shock.

The policy implications of these results are straightforward. Changes in Iranian political system in order to be more democratic, on one hand will control the military ambitions of the Iranian government and on the other hand will cause the Iranian government to pay increased attention

\footnotetext{
${ }^{6}$ These results are available upon request.
} 
to social, education and disciplinary issues. However these results are only significant in the short run.

Response to Cholesky One S.D. Innovations \pm 2 S.E.
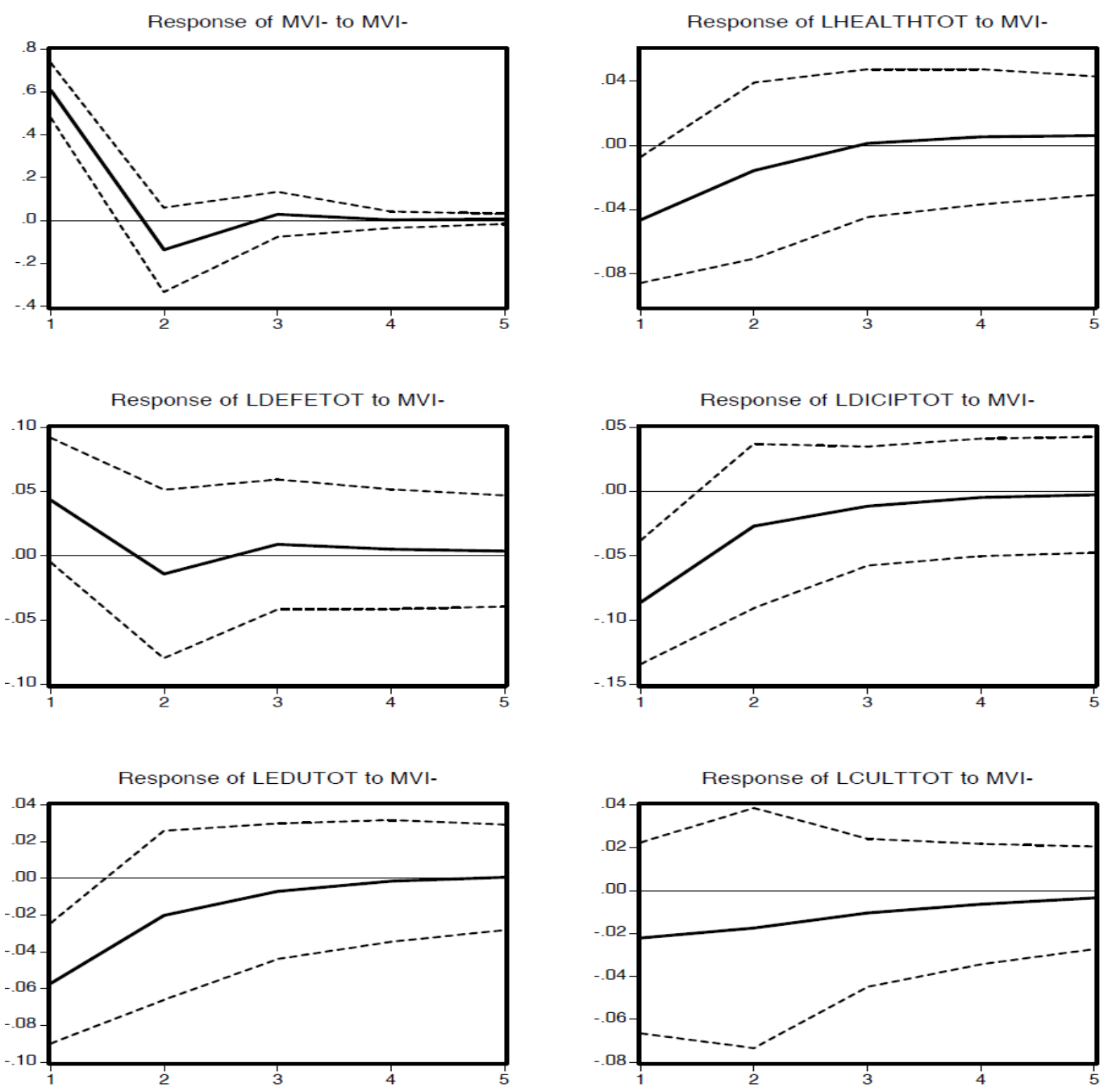

Fig.6. Impulse responses to one standard deviation shock in negative changes of Vanhanen index (MVI-)

Fig. 6 illustrates the response of the relative share of different components of government spending in total budget to negative changes in Vanhanen index. We use 1 lag of endogenous 
variables on the basis of different lag criteria, controlling for revolution and war with Iraq exogenous shocks ${ }^{7}$.

A one standard deviation increase in absolute values of "negative changes” of Vanhanen index for Iran accompanied with negative responses of the relative shares of government expenditures in health, disciplinary and education. However, these responses are only significant in the first year after initial shock. Although the military expenditures initially show positive responses to negative changes in Vanhanen index, but these responses are not significant.

In addition to Mork’s approach in defining the asymmetric shocks, we also use another definition suggested by Hamilton (1996). In consistence with Hamilton's work which has proposed an asymmetric definition of oil prices, we define the positive and negative changes in Vanhanen index (VI) as follows:

$\mathrm{HVI}_{\mathrm{t}}+=\max \left[0,\left(\left(\mathrm{HI}_{\mathrm{t}}\right)-\max \left(\left(\mathrm{HI}_{\mathrm{t}-1}\right), \ldots,\left(\mathrm{HI}_{\mathrm{t}-4}\right)\right)\right]\right.$

$\mathrm{HVI}_{\mathrm{t}^{-}}=\min \left[0,\left(\left(\mathrm{HI}_{\mathrm{t}}\right)-\min \left(\left(\mathrm{HI}_{\mathrm{t}-1}\right), \ldots,\left(\mathrm{HI}_{\mathrm{t}-4}\right)\right)\right]\right.$

Our findings show that the responses with Hamilton's definition of asymmetric shocks are similar to those which we obtained using Mork's definition. Therefore we have not reported them here ${ }^{8}$.

Using the ratio of government expenditures to GDP

As an alternative specification, we employ the ratio of each components of government spending to GDP instead of their relative share in budget in our impulse response analysis. How innovations in political variable (Polity2) affect the distribution of different categories of government spending to GDP ratio? First, we estimate an unrestricted VAR model with an

\footnotetext{
${ }^{7}$ The estimated VAR model satisfied the stability and cointegration conditions. The results of these tests are available upon request.

${ }^{8}$ The results with Hamilton's definition of asymmetric shocks are available upon request.
} 
optimum lag number of 2 (on the basis of different lag criteria) and Cholesky ordering of [Polity2, health to GDP ratio, military to GDP ratio, disciplinary to GDP ratio, education to GDP ratio, and cultural to GDP ratio]. As in previous analysis, we include revolution and war dummy variables as exogenous shocks. The diagnostic statistics such as VAR stability condition show that no root lies outside of the unit circle and the model is stable. The model also does not show a specific problem with residual autocorrelation on the basis of LM test. Moreover the results of cointegration tests reveal that at least three cointegrating vectors exist among the variables of interest $^{9}$.

Figure 7 shows that a one standard deviation increasing shock in Polity2 accompanied by initially negative responses in military spending to GDP ratio and positive responses in education, health, cultural and disciplinary expenditures to GDP ratios, reinforcing our earlier results using relative share of spending in the government budget. However, the significant responses are only for military expenditures (within the first year after initial shock) and education expenditures (within the second year after initial shock).

In short, sudden increases in democracy indexes feed the Iranian education expenditures and decrease the government expenditures in military issues. In other words in a more democratic environment, government will pay more attention to education issues and less attention to military issues ${ }^{10}$.

\footnotetext{
${ }^{9}$ The diagnostic statistic results are available upon request.

${ }^{10}$ In addition, we have estimated a VAR model using the per capita form of each components of government spending. We have estimated an unrestricted VAR model with a Cholesky ordering of [polity2, lhealthcap, ldefecap, ldicipcap, leducap, lcultcap]. We can find the significant responses only for the defense expenditures. The IRFs show that defense expenditures response both negatively and significantly (within the first 2 years after initial shock) to one standard deviation increasing shock in Polity2. We cannot find significant responses regarding to the other kind of expenditures. These results are available upon request.
} 
Response to Cholesky One S.D. Innovations \pm 2 S.E.
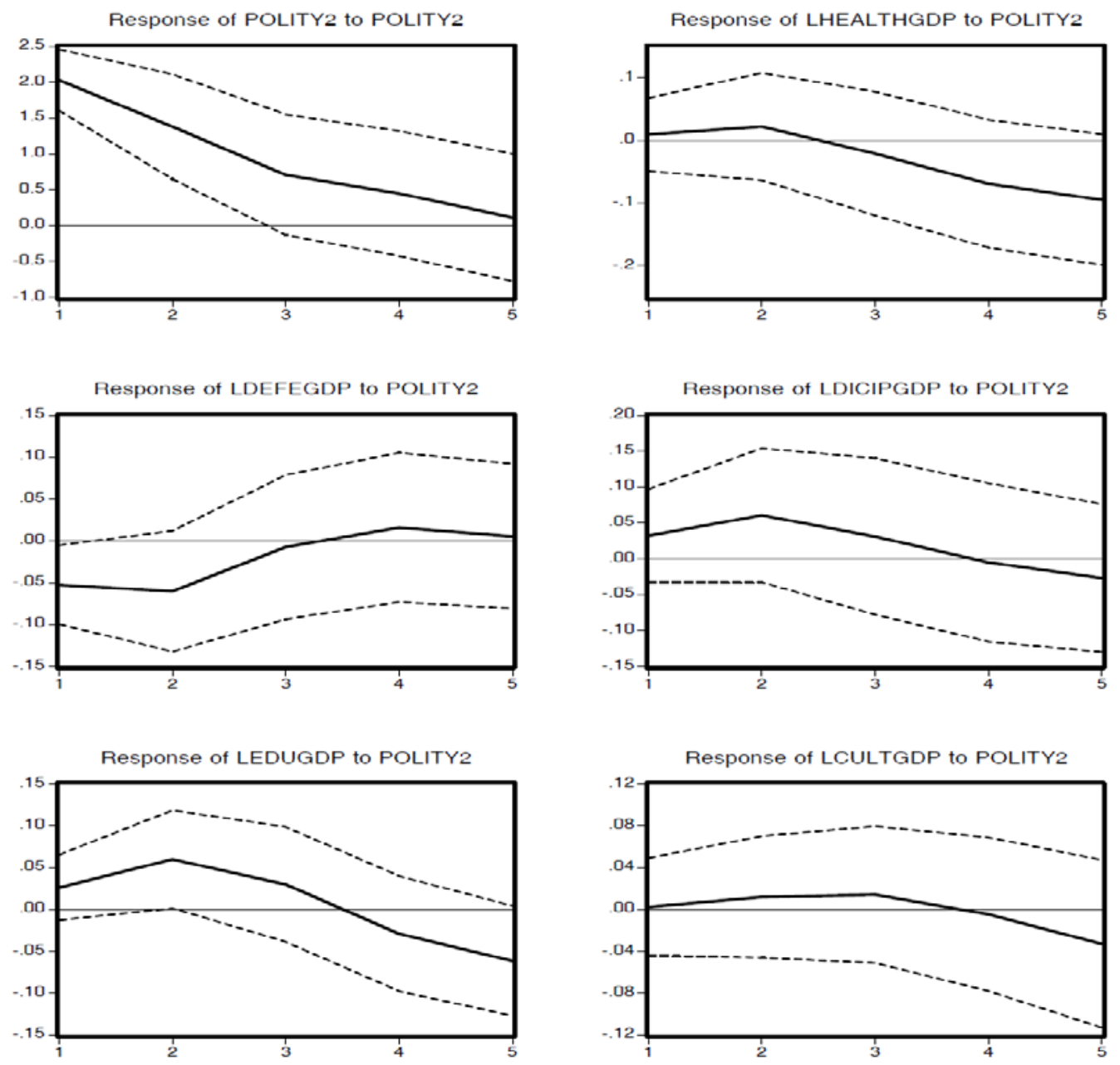

Fig 7.VAR responses to a shock in political variable (model with Polity2)

\section{Using the political variable as the response variable}

Our Variance Decomposition analysis showed that while the Polity2 variable plays a considerable role in explaining the shocks to the different categories of government expenditures, also the variations in different categories of government expenditures may affect the changes in Polity2 differently. In other words and from the political view we like to know if Iranian government is able to facilitate the democratizing process of country just by adjusting its 
spending behavior. We are interested in knowing how different categories of government expenditures can affect the political environment of Iran in order to be more democratic.

For this purpose we define another Cholesky ordering for our VAR model to deal with our political variable as a response variable instead of giving it the role of a shock variable.

Then we estimate an unrestricted VAR model with an optimum lag number of 2 (on the basis of different lag criteria) and Cholesky ordering of [health to GDP ratio, military to GDP ratio, disciplinary to GDP ratio, education to GDP ratio, cultural to GDP ratio, and Polity2]. In this VAR model we are interested in considering the responses of Polity2 as our political variable to the shocks to the different categories of government expenditures.

We include revolution and war dummy variables as exogenous shocks. The diagnostic statistics such as VAR stability condition show that no root lies outside of the unit circle and the model is stable. The model also does not show a specific problem with residual autocorrelation on the basis of LM test. Moreover the results of cointegration tests reveal that there are long run relationships among the variables of interest ${ }^{11}$.

\footnotetext{
${ }^{11}$ The diagnostic statistic results are available upon request.
} 
Response to Cholesky One S.D. Innovations \pm 2 S.E.

Response of POLITY2 to LHEALTHGDP

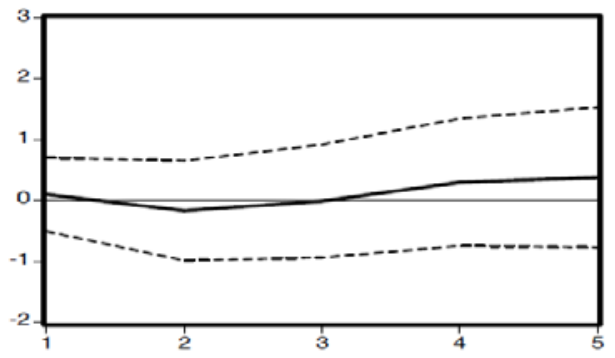

Response of POLITY2 to LDICIPGDP

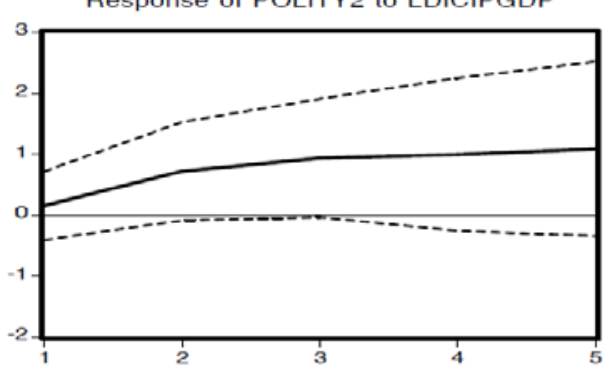

Response of POLITY2 to LCULTGDP

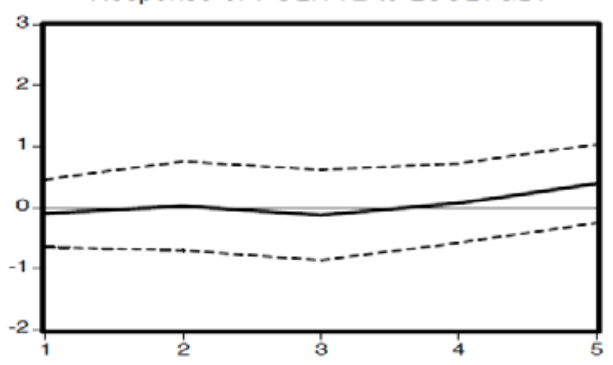

Response of POLITY2 to LDEFEGDP

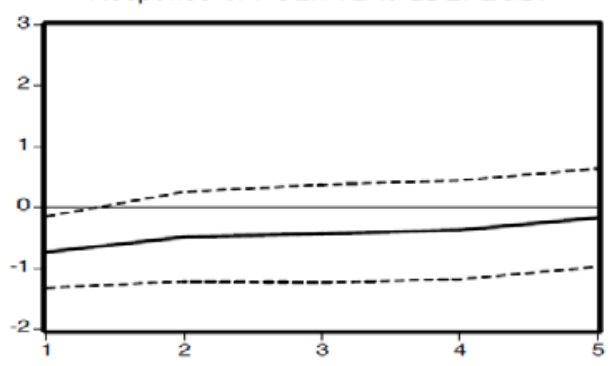

Response of POLITY2 to LEDUGDP

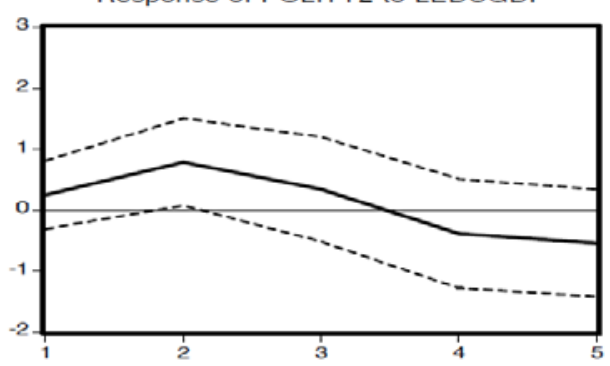

Response of POLITY2 to POLITY2

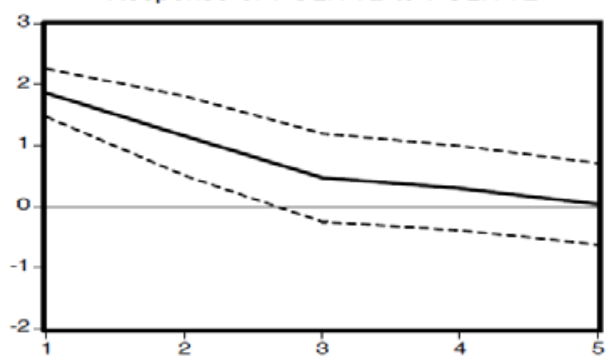

Fig 8.VAR responses of Polity2 to the shocks to the different components of government expenditures

Figure 8 shows that one standard deviation increasing shock in military expenditures cause negative changes on the Polity2 variable. Although this negative effect is significant only for the first year after the initial shock but it lasts till the end of the period. Moreover, Polity2 shows positive responses to the shocks to government expenditures in disciplinary and education. However these positive responses are significant only in the second year after the initial shock. 
The policy implications of these findings are important: Iranian government can improve the democracy indexes of the country by shifting its expenditures from military to education and also paying more attention to public order and protection of property rights.

\section{4- Conclusion}

We investigate the dynamic relationship between different kinds of government spending and quality of political institutions in Iran from 1960 to 2006, using impulse response functions and variance decomposition analysis. To what extent positive and negative shocks in quality of political institutions in Iran shape the allocation of budget to patronage (military) and public goods and services provision (education, and health among others) within the Iranian economy. Also what is the response of political institutions to shocks in each major group of spending in Iran: how shocks in the military budget shape the democratic institutions?

There is an increasing attention in scholarly and policy discussions on the effectiveness of sanctions to change the political institutions or behavior of Iran. Sanctions which reflect themselves in negative oil revenue shocks are proved to be of relevance for government budget allocation, especially regarding the significant response of military spending (Farzanegan, 2011). It is also shown that economic growth of Iran shows significant response to military spending shocks (Farzangean, 2012). However, one can also examine the responsiveness of political institutions to shocks in specific groups of government spending and also how the government budget responds to any significant shock in quality of political institutions.

The impulse response analysis which is helpful for our simulation shows that response of military spending to positive changes in quality democratic institutions in Iran is negative and statistically significant for 3 years after initial shock. This is an important finding. If the 
sanctions are successful to change the political behavior of Iran in short run (as is shown in

Dizaji and Bergeijk, 2013), then one can also expect to see a reduction in allocated budget for military means in Iran. In other words, lifting sanctions may repress the political openness and increase spending on military group in short term. In addition, our results contribute to the literature on patronage and public goods provision under different political regimes in a developing country.

\section{References}

Acemoglu, D., Davide T., Vindigni, A., 2010. A theory of military dictatorships. American Economic Journal: Macroeconomics, 2(1): 1-42.

Acemoglu, D., Robinson, J.A., 2006. Economic origins of dictatorship and democracy. Cambridge University Press.

Aidt, T.S., Dutta, J., Dauntan, M., 2010. The retrenchment hypothesis and the extension of the franchise in England and Wales. The Economic Journal 120, 990-1020.

Aidt, T.S., Dutta, J., Loukoianova, E., 2006. Democracy comes to Europe: franchise extension and fiscal outcomes 1830-1938. European Economic Review 50, 249-283.

Aidt, T.S., Eterovic, D.S., 2011. Political competition, electoral participation and public finance in 20th century Latin America. European Journal of Political Economy 27, 181-200.

Aidt, T.S., Jensen, P.S., 2009a. Tax structure, size of government, and the extension of the voting franchise in Western Europe, 1860-1938. International Tax and Public Finance 16, 362-394.

Aidt, T.S., Jensen, P.S., 2009b. The taxman tools up: an event history study of the introduction of the personal income tax. Journal of Public Economics 93, 160-175.

Barro, R.J., 1996. Democracy and growth. Journal of Economic Growth 1, 1-27.

Berument, M.H., Ceylan N. B., Dogan, N., 2010. The impact of oil price shocks on the economic growth of selected MENA countries. Energy Journal 31(1), 149-176.

Besley, T., Kudamatsu, M., 2006. Health and democracy. American Economic Review 96 (2) , 313-318.

Bjorvatn, K., Farzanegan, M. R., Schneider, F., 2013. Resource curse and power balance: evidence from Iran. Review of Middle East Economics and Finance 9, 133-158.

Boix, C., 2001. Democracy, development, and the public sector. American Journal of Political Science 45 (1), 1-17.

Boix, C., 2003. Democracy and Redistribution. Cambridge University Press.

Brown, D., Hunter, W., 2004. Democracy and human capital formation: education spending in Latin America, 1980-1997. Comparative Political Studies 37, 842-864. 
Brown, D., Hunter, W., 1999. Democracy and social spending in Latin America. American Political Science Review 93(4), 779-90.

BP, 2013. Statistical Review of World Energy 2013. Available at: http://www.bp.com/en/global/corporate/about-bp/statistical-review-of-world-energy2013.html

CBI, 2013. Annual National Accounts of Iran. Central bank of Iran. Available at: http://www.cbi.ir/page/2053.aspx. (November 29 2013).

Clements, M. P., Hendry, D.F., 1995. Forecasting in cointegrated systems. Journal of Applied Econometrics 10(2), 127-146.

Deacon, R.T., 2009. Public Good Provision under dictatorship and democracy. Public choice 139, 241-262.

Deacon, R. T., Saha, S., 2006. Public good provision by dictatorship: a survey. In A. F. Ott, \& R. J. Cebula (Eds.), The companion in public economics: empirical public economics. Cheltenham: Edward Elgar.

Dickey, D. A., Fuller, W. A., 1979. Distribution of the estimators for autoregressive time series with a unit root. Journal of the American Statistical Association 74, 427-431.

Dizaji, S. F., 2012. The effects of oil shocks on government expenditures and government revenues nexus in Iran (as a developing oil export based economy). ISS working paper No. 540.

Dizaji, S. F, Bergeijk, P. AG van., 2013. Potential early phase success and ultimate failure of economic sanctions: A VAR approach with an application to Iran. Journal of Peace Research 50(6), 721-736.

Doan, T., 2000. RATS version 5 User’s Guide. Estima, Evanston.

EIA, 2013. International Energy Statistics. US Energy Information Administration, Washington DC. Available at: http://www.eia.gov/cfapps/ipdbproject/iedindex3.cfm

Engle, R. F, Byung S. Y., 1987. Forecasting and testing in co-integrated systems. Journal of Econometrics 35(1), 143-159.

Farzanegan, M.R., Markwardt, G., 2009. The effects of oil price shocks on the Iranian economy. Energy Economics 31, 134-151.

Farzanegan, M.R., 2011. Oil revenue shocks and government spending behavior in Iran. Energy Economics 33, 1055-1069.

Farzanegan, M.R., 2012. Military spending and economic growth: the case of Iran. Defense and Peace Economics, iFirst Article, 1-23, DOI: http://dx.doi.org/10.1080/10242694.2012.723160

Franco, A., Alvarez-Dardet, C., Ruiz, M. T., 2004. Effect of democracy on health: ecological study. British Medical Journal 329, 1421-1423.

Fuller, W. A., 1976. Introduction to Statistical Time Series. New York: Wiley.

Funk, P., Gathmann, C., 2011. Does direct democracy reduce the size of government? New evidence from historical data, 1890-2000. The Economic Journal 121, 1252-1280.

GEM, 2013. Global Economic Monitor. The World Bank, Washington D.C. 
Govindaraj, R., Rannan-Eliya, R., 1994. Democracy, communism and health status: a crossnational study. Harvard University, School of Public Health, Data for Decision Making Project Working Papers: No. 7.2.

Hamilton, J.D., 1996. This is what happened to the oil price-macroeconomy relationship. Journal of Monetary Economics 38, 215-220.

Hausken, K., Martin, C.W., Plümper, T., 2004. Government spending and taxation in democracies and autocracies. Constitutional Political Economy 15, 239-259.

Habibi, N., 1994. Budgetary policy and political liberty: a cross-sectional analysis. World Development 22 (4), 579-586.

Helliwell J.F, 1994. Empirical linkages between democracy and economic growth. British Journal of Political Science 24, 225-248.

Hoffman, D. L., Rasche, R.H., 1996. Assessing forecast performance in a cointegrated system. Journal of Applied Econometrics 11(5), 495-517.

James P., Solberg E., Wolfson M., 1999. An identified systemic model of the democracy-peace nexus. Defense and Peace Economics 10, 1-38.

Johansen, S., Juselius, K., 1990. Maximum likelihood estimation and inference on cointegration-with applications to the demand for money. Oxford Bulletin of Economics and Statistics 52, 169-210.

Kaufman, R. R., Segura-Ubiergo, A., 2001. Globalization, domestic politics, and social spending in Latin America. World Politics 53(4), 553-587.

Lake, D., Baum, M., 2001. The invisible hand of democracy: political control and the provision of public services. Comparative Political Studies 34(6), 587-621.

Landman, T., 1999. Economic development and democracy: the view from Latin America. Political Studies 47, 607-626.

Lebovic J.H., 2001. Spending priorities and democratic rule in Latin America. Journal of Peace Research 45, 427-452.

Lipset, S. M., 1959. Some social prerequisites for democracy: economic development and political legitimacy. American Political Science Review 53, 69-105.

Marshall, M. G., Gurr, T.R., Jaggers, K.T., (2012) POLITYTM IV PROJECT: Dataset Users’. Manual Center for Systemic Peace.

Martin, C.W., Plümper, T., 2003. Democracy, government spending, and economic growth: a political-economic explanation of the Barro-effect. Public Choice 117, 27-50.

Mork, K.A., 1989. Oil and the marcoeconomy when prices go up and down: an extension of Hamilton's results. The Journal of Political Economy 97, 740-744.

Mork, K.A., 1994. Business cycles and the oil market. The Energy Journal 15, 15-38 (Special Issue).

Naka, A., Tufte, D., 1997. Examining impulse response functions in cointegrated systems. Applied Economics 29(12), 1593-1603.

Olson, M. 1993. Dictatorship, democracy, and development. The American Political Science Review 87, 567-576. 
Oneal J.R., Russett B.M., 1997. The classical liberals were right: democracy, interdependence and conflict, 1950-1985. International Studies Quarterly 41, 267_294

Persson, T., Tabellini, G., 2007. The growth effect of democracy: is it heterogeneous and how can it be estimated. NBER Working Papers, 13150.

Pesaran, M. H., Shin, Y., 1998. Generalised impulse response analysis in linear multivariate models. Economics Letters 58(1), 17-29.

Profeta, P., Puglisi,R., Scabrosetti, S., 2012, Does democracy affect taxation and government spending? Evidence from developing countries. Journal of Comparative Economics 41, 684-718.

Sasmal, J., 2011. Distributive politics, nature of government spending and economic growth in a low income democracy. Journal of Economics, Finance and Administrative Science 16, 31-49.

Saint-Paul, G., Verdier, T., 1993, Education, democracy and growth. Journal of Development Economics 42(2), 399-407.

Sims, C. A., 1980. Macroeconomics and reality. Econometrica 48, 1-48.

Sims, C. A., Stock, J., Watson, M., 1990. Inference in linear time series models with some unit roots. Econometrica 58(1), 113-144.

Snyder, J. M., Yackpvlev, I., 2000. Political and economic determinants of changes in government spending on social protection programs. mimeo, MIT, Cambridge, MA.

Stock, J. H., Watson, M., 2001. Vector autoregressions. Journal of Economic Perspectives 15(4), 101-115.

Tavares J., Wacziarg, R., 2001. How democracy affects growth. European Economic Review 45, 1341_1378.

Tijerina-Guajardo, J. A., Pagán, J.A., 2003. Government spending, taxation, and oil revenues in Mexico. Review of Development Economics 7(1), 152-164.

Vanhanen, T., 2011. Measures of Democracy 1810-2010. FSD1289, version 5.0. Tampere: Finnish Social Science Data Archive.

Vergne, C., 2009. Democracy, elections and allocation of public expenditures in developing countries. European Journal of Political Economy 25, 63-77.

Wacziarg, R., 2001. Human capital and democracy. mimeo, Stanford University, Stanford, CA.

Wintrobe, R., 2001. How to understand, and deal with dictatorship: an economist's view. Economics of Governance 2, 35-58.

Wintrobe, R., 2012. Autocracy and coups d’état'. Public Choice 152, 115-130.

Yildirim, J., Sezgin, S., 2005. Democracy and military expenditure: a cross-country evidence. Transition Studies Review 12(1), 93-100. 